\title{
No significant role for beta tubulin mutations and mismatch repair defects in ovarian cancer resistance to paclitaxel/cisplatin Bárbara Mesquita1 ${ }^{1}$, Isabel Veiga ${ }^{1}$, Deolinda Pereira ${ }^{2}$, Ana Tavares ${ }^{3}$, Isabel M Pinto ${ }^{3}$, Carla Pinto ${ }^{1}$, Manuel R Teixeira ${ }^{1}$ and Sérgio Castedo*1
}

\author{
Address: ${ }^{1}$ Department of Genetics, Portuguese Oncology Institute, 4200-072 Porto, Portugal, ${ }^{2}$ Department of Medical Oncology, Portuguese \\ Oncology Institute, 4200-072 Porto, Portugal and ${ }^{3}$ Department of Pathology, Portuguese Oncology Institute, 4200-072 Porto, Portugal \\ Email: Bárbara Mesquita - barbara-mesquita@portugalmail.pt; Isabel Veiga - isabelveiga@hotmail.com; \\ Deolinda Pereira - dpereira@ipoporto.min-saude.pt; Ana Tavares - genetica@ipoporto.min-saude.pt; \\ Isabel M Pinto - implaboratorio@mail.telepac.pt; Carla Pinto - carlapinto@portugalmail.pt; Manuel R Teixeira - mteixeir@ipoporto.min- \\ saude.pt; Sérgio Castedo* - genetica@ipoporto.min-saude.pt \\ * Corresponding author
}

Published: II August 2005

BMC Cancer 2005, 5:101 doi:10.1186/1471-2407-5-101
Received: 26 April 2005

Accepted: II August 2005

This article is available from: http://www.biomedcentral.com/I47I-2407/5//0I

(c) 2005 Mesquita et al; licensee BioMed Central Ltd.

This is an Open Access article distributed under the terms of the Creative Commons Attribution License (http://creativecommons.org/licenses/by/2.0), which permits unrestricted use, distribution, and reproduction in any medium, provided the original work is properly cited.

\begin{abstract}
Background: The mechanisms of chemoresistance in ovarian cancer patients remain largely to be elucidated. Paclitaxel/cisplatin combination is the standard chemotherapeutic treatment for this disease, although some patients do not respond to therapy. Our goals were to investigate whether TUBB mutations and mismatch repair defects underlie paclitaxel and cisplatin resistance.

Methods: Thirty-four patients with primary ovarian carcinomas (26 serous and eight clear cell carcinomas) treated with paclitaxel/cisplatin were analysed. TUBB exon 4 was analysed by nested $\mathrm{PCR}$ after a first round PCR using intronic primers. Microsatellite analysis was performed with the quasimonomorphic markers BAT 26 and BAT 34.

Results: Twenty-two of the 34 ovarian cancers (64.7\%) presented residual tumour after surgery, seven of which $(7 / 22 ; 31.8 \%)$ were shown to be chemoresistant (five serous and two clear cell tumours). Sequence analysis did not find any mutation in TUBB exon 4. Microsatellite instability was not detected in any of the ovarian carcinomas.
\end{abstract}

Conclusion: We conclude that TUBB exon 4 mutations and mismatch repair defects do not play a significant role in paclitaxel/cisplatin resistance.

\section{Background}

Ovarian cancer is the fourth most common cancer in women [1]. The standard treatment for ovarian cancer is cytoreductive surgery followed by combination systemic chemotherapy [2]. Since the middle 90's, the combination paclitaxel/cisplatin became the standard chemotherapeutic treatment for poor prognosis ovarian cancer [3]. Nevertheless, some patients are resistant to this chemo- therapeutic treatment, making it important to clarify the underlying mechanisms of resistance [4].

Paclitaxel binds to microtubules and causes kinetic suppression (stabilisation) of microtubule dynamics, promoting their polymerisation and cell cycle arrest in mitosis (antimitotic activity), which probably leads to apoptosis $[5,6]$. Microtubules are composed of a dimeric 
protein, tubulin, with alpha $(\alpha)$ and beta $(\beta)$ tubulin heterodimers in dynamic equilibrium. The $\beta$-tubulin gene (TUBB), mapped to 6p21.3 [7], is composed of four exons and encodes a 445-aminoacid protein with GTPase function to which paclitaxel preferentially binds [8]. Cisplatin is activated intracellularly and establishes inter- and intrastrand DNA adducts that block replication and translation. The fate of cells after cisplatin exposure depends both on the extent of DNA damage and the cellular response to it, and apoptosis can be induced as a consequence [5,9]. Although the specific mechanism that triggers apoptosis is not totally clear, some evidence suggests that this process can be mediated by the DNA mismatch repair system (MMR) $[5,9]$.

Drug resistance is considered a multifactorial process, but the detailed mechanisms are still unknown. Recently, point mutations in the $\beta$-tubulin gene, predominantly in exon 4, were associated with resistance to paclitaxel [1012]. Resistance to cisplatin was linked with anomalies in the DNA MMR system resulting in microsatellite instability (MSI) [13-16]. In order to evaluate the relevance of these mechanisms to ovarian cancer chemoresistance, we screened TUBB exon 4 for mutations and performed MSI analysis in 34 ovarian carcinomas treated with paclitaxel/ cisplatin and evaluated patients' response to chemotherapy.

\section{Methods}

\section{Patient data}

Thirty-four primary ovarian carcinoma patients, of serous (26 cases) or clear cell (eight cases) histological types (invasive or borderline), consecutively admitted at the Portuguese Oncology Institute - Porto and treated with the adjuvant chemotherapy scheme paclitaxel/cisplatin, were analysed. Patients previously treated with other chemotherapeutic regimens or radiotherapy were excluded from the study.

Evaluation of treatment responses was done by an oncologist using computerized tomography or magnetic resonance and CA125 quantification, according to international guidelines [17]. Investigators performing laboratory analysis were not aware of chemotherapy response or resistance until the study was completed.

\section{DNA extraction}

Genomic DNA was extracted from chemo-naïve, paraffin embedded tumours, after dissection. Tissue blocks were sectioned, mounted on glass slides, deparaffinised, and stained with haematoxylin and eosin. Tumour areas were identified under the microscope on each slide and marked. Areas with at least $70 \%$ of cancer cells were identified on tissue sections. Selected paraffin blocks were sectioned ( $5 \mu \mathrm{m}$ sections) and mounted in microscope slides.
Marked tumour areas were selected with a sterile razor blade. Three sections of tissue were incubated in a solution of $10 \mathrm{mM}$ Tris- $\mathrm{HCl}$ buffer (pH 8.0), $2.5 \mathrm{mM} \mathrm{MgCl}_{2}$, $50 \mathrm{mM} \mathrm{KCl}, 0.5 \%$ (p/v) Tween 20 , and $1 \mathrm{mg} / \mathrm{mL}$ proteinase $\mathrm{K}$ for 48 hours at $55^{\circ} \mathrm{C}$.

\section{TUBB exon 4 sequencing}

For polymerase chain reaction (PCR) assays, different sets of oligonucleotides were designed to amplify specific regions of TUBB exon 4 that code for the GTP and paclitaxel binding sites. To assure that the amplicon was not a pseudogene, the following intronic primer set was used in the first round PCR: 5'AAG-GAG-ATA-CAT-CCG-AGGGAA-TT3' and 5'AAG-GTA-TTC-ATG-ATG-CGA3'. After checking for first round PCR product in an agarose gel, a 1:10 dilution was used for nested PCRs with the following primers: set 1, 5'AGA-GAG-CTG-TGA-CTG-CCT-G3' and 5'AAG-GTA-TTC-ATG-ATG-CGA3'; set 2， 5'GCT-CTGGAA-TGG-GCA-CTC3' and 5'CCG-TAG-GTT-GGT-TGTGGT-CA3'; set 3，5'CGG-GGA-TCT-GAA-CCA-CCT-T3' and 5'GAG-TGT-CAC-GGC-CTG-GAG-T3'. The PCR products were separated by electrophoresis in agarose gels stained with ethidium bromide and analysed in a transiluminator. All DNA samples were analysed in an automatic DNA sequencer ABI PRISM $310^{\mathrm{TM}}$ Genetic Analyser. The sequences were compared with the genomic sequence GenBank AF070600.

\section{MSI evaluation}

For microsatellite analysis, tumour DNA was amplified with primers for two quasimonomorphic markers BAT 26 (5'GAG-TGT-CAC-GGC-CTG-GAG-T3'; 5'AAC-CAT-TCAACA-TTT-TTA-ACC-C3') and BAT 34 (5'ACC-CTG-GAGGAT-TTC-ATC-TC3'; 5'AAC-AAA-GCG-AGA-CCC-AGTCT3') [18-20]. Fragments were analysed in an ABI PRISM $310^{\mathrm{TM}}$ Genetic Analyser.

\section{Results}

Twenty-two of the 34 ovarian cancers (64.7\%) presented residual tumour after surgery, seven of which (7/22; $31.8 \%$ ) were shown to be chemoresistant (five serous and two clear cell tumours) (Table 1).

Amplicons of 700 bp were observed for all cases after amplification with the intronic primers (data not shown). Nested PCR with primer sets 1-3 specific for TUBB exon 4 resulted in amplicons with 129, 254, and 201 bp, respectively (Figure 1). Sequencing analysis of all 34 cases showed no TUBB exon 4 mutations (Figure 2).

Microsatellite analysis with markers BAT 26 and BAT 34 (Figure 3) showed the normal pattern in all cases, so no evidence for microsatellite instability was detected in this series. 
Table I: Clinical, pathological and genetic data of 34 ovarian cancer patients.

\begin{tabular}{|c|c|c|c|c|c|c|c|}
\hline Patient & $\begin{array}{c}\text { Histological } \\
\text { type }\end{array}$ & Stage & Grade & $\begin{array}{l}\text { Residual } \\
\text { tumour }\end{array}$ & $\begin{array}{l}\text { Treatment } \\
\text { response }\end{array}$ & $\begin{array}{c}\text { Exon } 4 \text { TUBB } \\
\text { mutation }\end{array}$ & MSI status \\
\hline 1 & Serous & III & 1 & $>2 \mathrm{~cm}$ & $C R$ & Not present & Stable \\
\hline 2 & Serous & III & 2 & $<2 \mathrm{~cm}$ & CR & Not present & Stable \\
\hline 3 & Serous & III & 3 & $>2 \mathrm{~cm}$ & $\mathrm{CR}$ & Not present & Stable \\
\hline 4 & Serous & III & 1 & $>2 \mathrm{~cm}$ & WR & Not present & Stable \\
\hline 5 & Serous & III & 2 & $>2 \mathrm{~cm}$ & $C R$ & Not present & Stable \\
\hline 6 & Serous & III & 2 & $<2 \mathrm{~cm}$ & CR & Not present & Stable \\
\hline 7 & Serous & III & 3 & $>2 \mathrm{~cm}$ & $C R$ & Not present & Stable \\
\hline 8 & Serous & III & 3 & $>2 \mathrm{~cm}$ & $C R$ & Not present & Stable \\
\hline 9 & Serous & III & 3 & $>2 \mathrm{~cm}$ & $\mathrm{CR}$ & Not present & Stable \\
\hline 10 & Serous & III & 3 & $>2 \mathrm{~cm}$ & $C R$ & Not present & Stable \\
\hline 11 & Serous & III & 3 & $>2 \mathrm{~cm}$ & $\mathrm{CR}$ & Not present & Stable \\
\hline 12 & Serous & III & 3 & $>2 \mathrm{~cm}$ & WR & Not present & Stable \\
\hline 13 & Serous & III & 3 & $>2 \mathrm{~cm}$ & WR & Not present & Stable \\
\hline 14 & Serous & IV & 3 & $>2 \mathrm{~cm}$ & PR & Not present & Stable \\
\hline 15 & Serous & IV & 3 & $>2 \mathrm{~cm}$ & $\mathrm{CR}$ & Not present & Stable \\
\hline 16 & Serous & IV & 3 & $>2 \mathrm{~cm}$ & WR & Not present & Stable \\
\hline 17 & Serous & IV & 3 & $>2 \mathrm{~cm}$ & WR & Not present & Stable \\
\hline 18 & Serous & IV & 3 & $<2 \mathrm{~cm}$ & $\mathrm{CR}$ & Not present & Stable \\
\hline 19 & Serous & 1 & 1 & Absent & - & Not present & Stable \\
\hline 20 & Serous & ॥ & 3 & Absent & - & Not present & Stable \\
\hline 21 & Serous & III & 1 & Absent & - & Not present & Stable \\
\hline 22 & Serous & III & 3 & Absent & - & Not present & Stable \\
\hline 23 & Serous & III & I & Absent & - & Not present & Stable \\
\hline 24 & Serous & II & B & Absent & - & Not present & Stable \\
\hline 25 & Serous & II & B & Absent & - & Not present & Stable \\
\hline 26 & Serous & III & B & Absent & - & Not present & Stable \\
\hline 27 & Clear cell & 1 & 3 & $<2 \mathrm{~cm}$ & $\mathrm{CR}$ & Not present & Stable \\
\hline 28 & Clear cell & II & 3 & $>2 \mathrm{~cm}$ & WR & Not present & Stable \\
\hline 29 & Clear cell & III & 3 & $>2 \mathrm{~cm}$ & PR & Not present & Stable \\
\hline 30 & Clear cell & IV & 3 & $>2 \mathrm{~cm}$ & WR & Not present & Stable \\
\hline 31 & Clear cell & 1 & 3 & Absent & - & Not present & Stable \\
\hline 32 & Clear cell & 1 & 3 & Absent & - & Not present & Stable \\
\hline 33 & Clear cell & II & 3 & Absent & - & Not present & Stable \\
\hline 34 & Clear cell & III & 3 & Absent & - & Not present & Stable \\
\hline
\end{tabular}

B: borderline tumours; CR: complete response; PR: partial response; WR: without response. The stage classification was according to the Federation Internationale de Gynecologie [2I] and grading was defined as well differentiated (I), moderately differentiated (2), and poorly differentiated (3).

\section{Discussion}

Tumour resistance to chemotherapy or disease relapses resistant to further treatment after an initial response are common events in current cytotoxic cancer treatment regimens [5]. With regard to ovarian cancer chemotherapy, the current major challenge is to understand why histologically similar tumours behave so differently when treated with the same chemotherapeutic regimen. The action of a drug potentially depends on several mechanisms, namely, metabolisation, access into the tumour microenvironment, intracellular uptake, interaction with the target, and subsequent signalling events [5]. It is therefore important to study the different molecular mechanisms that can be involved in chemotherapy resistance.
The rationale for studying the relationship between TUBB gene mutations with paclitaxel resistance came from the studies of Giannakakou et al and Gonzalez-Garay et al $[10,11]$, who found TUBB mutations in ovarian cancer cell lines and in hamster cells, respectively. Subsequently, Monzó et al [12] reported TUBB mutations in 16 out of 36 $(44.4 \%)$ paclitaxel resistant tumour samples from patients with advanced non-small cell lung cancer and proposed that $T U B B$ mutations could represent a possible mechanism of paclitaxel resistance in that tumour type.

However, our findings in the present study argue against a significant role of TUBB gene mutations in paclitaxel resistance in ovarian cancer. In keeping with our results, 


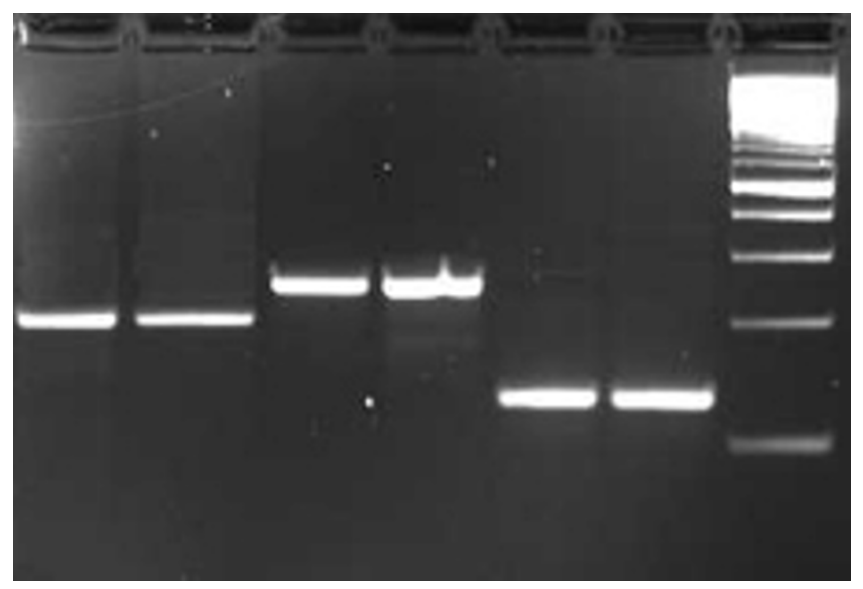

Figure I

Nested PCR products (in duplicate) obtained with the three primer sets specific for TUBB exon 4 in an ovarian carcinoma (from right to left, lane I: 100 bp step ladder; lanes 2 and 3: I 29 bp amplicon - set I primers; lanes 4 and 5: 254 bp amplicon - set 2 primers; lanes 6 and 7: 20I bp amplicon - set 3 primers).

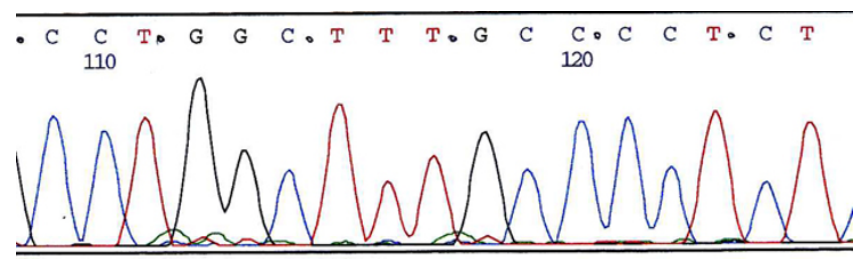

Figure 2

Electrophorogram of part of TUBB exon 4 without any sequence variation in an ovarian carcinoma.

Sale et al [22] and Lamendola et al [23] did not detect TUBB gene mutations in ovarian cancer samples. Similar findings have recently been obtained for several other tumour types, namely, lung [24], breast [25,26], and gastric cancer [27]. Taken together, our and several other investigations concur that TUBB exon 4 mutations are not an important mechanism underlying paclitaxel resistance. To explain the early findings of Monzó et al [12], which were not reproduced by other authors, including the present study, Kelley et al [24] suggested that the primers used by Monzó et al [12] did not allow to discriminate $T U B B$ from its pseudogenes [24]. Furthermore, the first studies reporting $T U B B$ gene mutations were made in hamster cells [11] and in ovarian cancer cell lines [10] after selection by paclitaxel exposure, something that
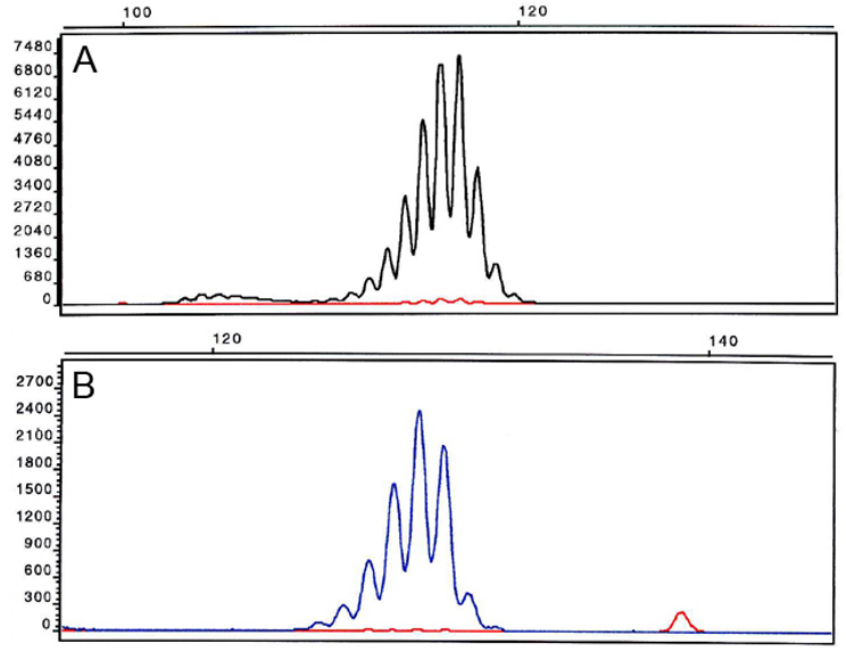

Figure 3

Electrophorograms of BAT 26 (A) and BAT 34 (B) markers in an ovarian carcinoma, showing the same pattern found in normal control DNA.

makes difficult a direct extrapolation of these findings to human tumours.

We have also evaluated the MSI status of the 34 ovarian carcinomas with quasimonomorphic BAT 26 and BAT 34 markers, but did not find any microsatellite unstable tumours. Some authors have described an association between cisplatin resistance and MMR system anomalies in ovarian adenocarcinomas [28-30], as well as in colon cancer cell lines [31-33]. Additionally, other studies found MSI in ovarian cancer, namely, in serous and clear cell histological types [34-40]. However, the frequency of MSI identified in those studies was quite low (0-14.3\%), which is in agreement with our findings. To completely rule out any relationship between deficient mismatch repair and cisplatin resistance, one would have to analyse more microsatellite markers in a larger series of tumours paired with normal DNA.

\section{Conclusion}

We conclude that, contrarily to earlier suggestions, TUBB exon 4 mutations and MMR defects are not major mechanisms underlying paclitaxel and/or cisplatin resistance in ovarian cancer. Further investigation on alternative mechanisms of resistance to these drugs is warranted. Possible mechanisms to paclitaxel resistance are P-glycoprotein overexpression $[5,41]$, differential $\beta$-tubulin isotype expression [5,42,43], and apoptosis deregulation [5,4446]. Decrease in intracellular cisplatin level, increase of tolerance or repair of DNA lesions, and alterations in the 
apoptotic cascade have also been related with cisplatin resistance $[5,47]$. These studies are necessary to predict individual response of patients to these chemotherapeutic agents.

\section{Competing interests}

The author(s) declare that they have no competing interests.

\section{Authors' contributions}

BM carried out the molecular genetic studies and drafted the manuscript. IV participated in the design of the study and coordination. DP was responsible for clinical surveillance. AS was responsible for paraffin slides. IMP was responsible for the histopathologic analysis. CP carried out sequence alignment. MT coordinated the study. SC conceived the study and participated in its design and coordination.

\section{Acknowledgements}

We thank the Portuguese Health Ministry for the financial support (Project nr. 191/99). B. Mesquita was a fellow of Fundação para Ciência e Tecnologia. We thank Mariano Monzó and collaborators for useful discussions during this work.

\section{References}

I. Parkin DM, Bray FI, Devesa SS: Cancer burden in the year 2000: the global picture. Eur J Cancer 200I, 37:S4-66.

2. Crown J, O'Leary M: The taxanes: an update. Lancet 2000, 355:1176-1178.

3. Piccart MJ, Bertelsen K, James K, Cassidy J, Mangioni C, Simonsen E, Stuert G, Kaye S, Vargote I, Blom R, Grimshaw R, Atkinson RJ, Swenerton KD, Trope C, Nardi M, Kaern J, Tumolo S, Timmers P, Roy JA, Lhoas F, Lindvall B, Bacon M, Birt A, Andersen JE, Zee B, Paul J, Baron $B$, Pecorelli S: Randomized intergroup trial of cisplatin-paclitaxel versus cisplatin-cyclophosphamide in women with advanced epithelial ovarian cancer: three year results. J Natl Cancer Inst 2000, 92:699-708.

4. McGuire, Ozols RF: Chemotherapy in advanced ovarian cancer. Semin Oncol 1998, 25:340-348.

5. Agarwal R, Kaye SB: Ovarian cancer: strategies for overcoming resistance to chemotherapy. Nat Rev Cancer 2003, 3:502-5I6.

6. Wang TH, Wang HS, Soong YK: Paclitaxel-induced cell death: where the cell cycle and apoptosis come together. Cancer 2000, 88:2619-2628.

7. Floyd-Smith GA, de Martinville B, Francke U: An expressed tubulin gene, TUBB, is located on the short arm of human chromosome 6 and two related sequences are dispersed on chromosome 8 and 13. Exp Cell Res 1986, 163:539-548.

8. Ludueña RF: Multiple forms of tubulin: different gene products and covalent modifications. Int Rev Cytol 1998, I 78:207-275.

9. Perez RP: Cellular and molecular determinants of cisplatin resistance. Eur J Cancer 1998, 34:1535-1542.

10. Giannakakou P, Sackett DL, Kang YK, Zhan Z, Butters JT, Fojo T, Poruchynsky MS: Paclitaxel-resistant human ovarian cancer cells have mutant $\beta$-tubulins that exhibit impaired paclitaxeldriven polymerization. J Biol Chem 1997, 272:171 I8-17|25.

II. Gonzalez-Garay ML, Chang L, Blade K, Menick DR, Cabral F: A $\beta$ tubulin leucine cluster involved in microtubule assembly and paclitaxel resistance. J Biol Chem 1999, 27 I:23875-23882.

12. Monzó M, Rosell R, Sanchéz JJ, Lee JS, O'Brate A, Gonzalez-Larriba JL, Alberola V, Lorenzo JC, Nunez L, Ro JY, Martin C: Paclitaxel resistance in non-small cell lung cancer associated with $\beta$-tubulin gene mutations. J Clin Oncol 1999, 17:1786-1793.

13. de las Alas MM, Aebi S, Fink D, Howell SB, Los G: Loss of DNA mismatch repair: effects on the rate of mutation to drug resistance. J Natl Cancer Inst 1997, 89: I537-I54I.
14. Vaurs C, Bignon YJ: Quoi de neuf sur la signification des instabilités microssatellitaires dans les pathologies tumorales humaines? Bull Cancer 1997, 84:106I-107I.

15. Fink D, Aebi S, Howell SB: The role of DNA mismatch repair in drug resistance. Clin Cancer Res 1998, 4: I-6.

16. Lage H, Dietel M: Involvement of the DNA mismatch repair system in antineoplastic drug resistance. J Cancer Res Clin Oncol 1999, I 25:156-165.

17. Soignet SL, Spriggs DR: General principles of chemotherapy. In Handbook of Gynecologic Oncology Edited by: Barakat RR, Bevers MW, Gershenson DM. London: Martin Dunitz; 200I:243-263.

18. Hoang JM, Cottu PH, Thuille B, Salmon RJ, Thomas G, Hamelin R: BAT - 26, an indicator of the replication error phenotype in colorectal cancers and cell lines. Cancer Res 1997, 57:300-303.

19. Zhou XP, Hoang JM, Li YJ, Seruca R, Carneiro F, Sobrinho-Simoes M, Lothe RA, Gleeson CM, Russel SE, Muzeau F, Flejou JF, Hoang-Xuan L, Lidereau R, Thomas G, Hamelin R: Determination of the replication error phenotype in human tumors without the requirement for matching normal DNA by analysis of mononucleotide repeat microsatellites. Genes Chromosomes Cancer 1998, 21:101-107.

20. Lamb P, Crawford L: Characterization of the human P53 gene. Mol Cell Biol I 986, 6: I 379-1385.

21. Benedet JL, Bender H, Jones H III, Ngan HYS, Pecorelli S: FIGO staging classifications and clinical practice guidelines in the management of gynecologic cancers. FIGO Committee on Gynecologic Oncology. Int J Gynaecol Obstet 2000, 70:209-262.

22. Sale S, Sung R, Shen P, Yu K, Wang Y, Duran GE, Kim JH, Fojo T, Oefner PJ, Sikic Bl: Conservation of the class I $\beta$-tubulin gene in human populations and lack of mutations in lung cancers and paclitaxel-resistant ovarian cancers. Mol Cancer Ther 2002, I:215-225.

23. Lamendola DE, Duan Z, Penson RT, Oliva E, Seiden MV: Beta tubulin mutations are rare in ovarian carcinoma. Anticancer Res 2003, 23:68I-686.

24. Kelley MJ, Li S, Harpole DH: Genetic analysis of the $\beta$-tubulin gene, TUBB, in non-small-cell lung cancer. J Nat Cancer Inst 200I, 93: I886-I888.

25. Hasegawa S, Miyoshi Y, Egawa C, Ishitobi M, Tamaki Y, Monden M, Nogushi S: Mutational analysis of the class I beta-tubulin gene in human breast cancer. Int J Cancer 2002, I0I:46-5I.

26. Maeno K, Ito K, Hama Y, Shingu K, Kimura M, Sano M, Nakagomi H, Tsuchiaya S, Fujimori M: Mutation of the class I $\beta$-tubulin gene does not predict response to paclitaxel for breast cancer. Cancer Lett 2003, 198:89-97.

27. Urano N, Fujiwara Y, Hasegawa S, Miyoshi Y, Nogushi S, Takiguchi S, Yasuda T, Yano M, Monden M: Absence of beta-tubulin gene mutation in gastric carcinoma. Gastric Cancer 2003, 6: $108-112$.

28. Orth K, Hung J, Gazdar A, Bowcock A, Mathis JM, Sambrook J: Genetic instability in human ovarian cancer cell lines. Proc Natl Acad Sci USA 1994, 91:9495-9499.

29. Aebi S, Haidar BK, Gordon R, Cenni B, Zheng H, Fink D, Christen RD, Boland CR, Koi M, Fishel R, Howell SB: Loss of DNA mismatch repair in acquired resistance to cisplatin. Cancer Res 1996, 56:3087-3090.

30. Fink D, Nebel S, Norris PS, Baergen RN, Wilczynski SP, Costa MJ, Haas M, Cannistra SA, Howell SB: Enrichment for DNA mismatch repair deficient cells during treatment with cisplatin. Int J Cancer 1998, 77:74I-746.

3I. Fink D, Nebel S, Aebi S, Zheng H, Cenni B, Nheme A, Christen RD, Howell $S B$ : The role of DNA mismatch repair in platinum drug resistance. Cancer Res 1996, 56:488I-4886.

32. Aebi S, Fink D, Gordon R, Kim HK, Zheng H, Finj JL, Howell SB: Resistance to cytotoxic drugs in DNA mismatch repair-deficient cells. Clin Cancer Res 1997, 3:1763-1767.

33. Fink D, Zheng H, Nebel S, Norris PS, Aebi S, Lin TP, Nehme A, Christen $R D$, Haas $M$, MacLeod $C L$, Howell $S B$ : In vitro and in vivo resistance to cisplatin in cells that have lost DNA mismatch repair. Cancer Res 1997, 57:1841-1845.

34. Fujita M, Enomoto T, Yoshino K, Nomura T, Buzard GS, Inoue M, Okudaira $Y$ : Microsatellite instability and alterations in the hMSH2 gene in human ovarian cancer. Int J Cancer 1995, 64:361-366.

35. Pieretti M, Cavalieri C, Conway PS, Gallion HH, Powell DE, Turker MS: Genetic alterations distinguish different types of ovarian tumors. Int J Cancer 1995, 64:434-440. 
36. Arzimanoglou II, Lallas T, Osborne M, Barber H, Gilbert F: Microsatellite instability differences between familial and sporadic ovarian cancers. Carcinogenesis 1996, I 7:1799-I804.

37. Haas CJ, Diebold J, Hirschmann A, Rohrbach H, Schid S, Lohrs U: Microsatellite analysis in serous tumors of the ovary. Int J Gynecol Pathol 1999, I8:158-162.

38. Geisler JP, Goodheatr MJ, Sood AK, Holmes RJ, Hatterman-Zogg MA, Buller RE: Mismatch repair gene expression defects contribute to microsatellite instability in ovarian carcinoma. Cancer 2003, 98:2199-2206.

39. Cai KQ, Albarracin C, Rosen D, Zhong R, Zheng W, Luthra R, Broaddus $\mathrm{R}$, Liu J: Microsatellite instability and alteration of the expression of the hMLHI and hMSH2 in ovarian clear cell carcinoma. Hum Pathol 2004, 35:552-559.

40. Singer G, Kallinowski T, Hartmann A, Dietmaier W, Wild PJ, Schraml $P$, Sauter G: Different types of microsatellite instability in ovarian carcinoma. Int J Cancer 2004, I I 2:643-646.

4l. Parekh H, Wiesen K, Simpkins H: Acquisition of taxol resistance via P-glycoprotein and non-P-glycoprotein-mediated mechanisms in human ovarian carcinoma cells. Biochem Pharmacol 1997, 53:46|-470.

42. Ranganathan S, Benetatos CA, Colarusso PJ, Dexter DW, Hudes GR: Altered $\beta$-tubulin isotype expression in paclitaxel resistant human prostate carcinoma cells. Brit J Cancer 1998, 77:562-566.

43. Kavallaris M, Burkhart CA, Horowitz SB: Antisense oligonucleotides to class III $\beta$-tubulin sensitize drug-resistant cells to Taxol. Brit J Cancer 1999, 80:1020-1025.

44. Haldar S, Basu A, Croce CM: Bcl2 is the guardian of microtubule integrity. Cancer Res 1997, 57:229-233.

45. Liu JR, Fletcher B, Page C, Hu C, Nunez G, Baker V: Bcl-xL is expressed in ovarian carcinoma and modulates chemotherapy-induced apoptosis. Gynecol Oncol 1998, 70:398-403.

46. Tai YT, Lee S, Niloff E, Weisman C, Strobel T, Cannistra SH: BAX protein expression and clinical outcome in epithelial ovarian cancer. J Clin Oncol 1998, 16:2583-2590.

47. Perego P, Romanelli S, Carenini N, Magnani I, Leone R, Bonetti A, Paolicchi A, Zunino F: Ovarian cancer cisplatin-resistant cell lines: multiple changes including collateral sensitivity to taxol. Ann Oncol 1998, 9:423-430.

\section{Pre-publication history}

The pre-publication history for this paper can be accessed here:

http://www.biomedcentral.com/1471-2407/5/101/pre pub

\section{Publish with Bio Med Central and every scientist can read your work free of charge}

"BioMed Central will be the most significant development for disseminating the results of biomedical research in our lifetime. "

Sir Paul Nurse, Cancer Research UK

Your research papers will be:

- available free of charge to the entire biomedical community

- peer reviewed and published immediately upon acceptance

- cited in PubMed and archived on PubMed Central

- yours - you keep the copyright 